2014, volume 3, issue 2

Zaremba A., Żmudziński R. (2014). IPO Initial Underpricing Anomaly: the Election Gimmick Hypothesis. Copernican Journal of Finance \& Accounting, 3(2), 167-181. http://dx.doi.org/10.12775/ CJFA.2014.025

\author{
AdAM Zaremba*, RADOSKAW ŻMUDZIŃSKI ${ }^{* *}$ \\ Poznań University of Economics
}

\title{
IPO INITIAL UNDERPRICING ANOMALY: THE ELECTION GIMMICK HYPOTHESIS
}

Keywords: IPO underpricing, political cycles, stock market anomalies, Warsaw Stock Exchange.

J E L Classification: G12, G18, G32.

Abstract: The relationship between political motivations and underpricing of public offerings of privatized companies is to a great extend unexplored field in the global academic literature. In this paper we offer a new explanation for the IPO underpricing anomaly. We formulate the election gimmick hypothesis, which states that in order to please the voters the treasury may be motivated to leave some money on the table during the IPOs of state-owned enterprises. We test the practical implications of the hypothesis. First we review the previous literature, next we perform empirical research based on a filtered sample of 250 IPOs on the Polish market in years 2005-2013. We examine the abnormal returns in the sample and employing some regression - and simulation-based methods we examine the sources and variation in underpricing. Our findings suggest that the IPOs of state-owned enterprises are more underpriced than remaining ones and that there is more money left on the table in the months preceding elections.

Date of submission: June 22, 2014; date of acceptance: September 19, 2014.

* Contact information: adam.zaremba@ue.poznan.pl, Department of Investment and Capital Markets, Poznań University of Economics, al. Niepodległości 10, 61-875 Poznań, Poland, phone: 618543828.

** Contact information: radoslaw.zmudzinski@ue.poznan.pl, Department of Investment and Capital Markets, Poznań University of Economics, al. Niepodległości 10, 61-875 Poznań, Poland. 


\title{
ANOMALIA NADWYŻKOWYCH NATYCHMIASTOWYCH STÓP ZWROTU PO DEBIUTACH: HIPOTEZA KIEŁBASY WYBORCZEJ
}

Słowa kluczowe: niedoszacowanie cen ofertowych IPO, cykle polityczne, anomalie giełdowe, Giełda Papierów Wartościowych w Warszawie.

Klasyfikacja J E L: G12, G18, G32.

\begin{abstract}
Abstrakt: Zależności pomiędzy motywacjami politycznymi a niedoszacowaniem ofert pierwotnych prywatyzowanych spółek stanowi w znacznej mierzenie niezbadany obszar. W niniejszym artykule zaproponowane zostaje nowe częściowe wyjaśnienie dla anomalii nadwyżkowych natychmiastowych stóp zwrotu po debiucie. Sformułowana zostaje „hipotezę kiełbasy wyborczej”, która zakłada, że przed wyborami skarb państwa może być zmotywowany, aby celowo „pozostawiać pieniądze na stole” podczas prywatyzacji przedsiębiorstw państwowych. Po dokonaniu przeglądu literatury, przeprowadzone zostają badania empiryczne na przefiltrowanej próbie 250 IPO na polskim rynku kapitałowym w latach 2005-2013. Przy pomocy analizy regresji i metod symulacyjnych, przebadane zostają nadwyżkowe stopy zwrotu oraz źródła ich przekrojowej zmienności. Wyniki badań wskazują, że prywatyzowane spółki państwowe podczas debiutów charakteryzują się większym niedoszacowaniem aniżeli pozostałe firmy, oraz że w miesiącach poprzedzających wybory „na stole pozostawiane jest więcej pieniędzy" dla inwestorów.
\end{abstract}

\section{INTRODUCTION}

The IPO anomalies are phenomena frequently investigated by financial economists. The three most popular - the initial IPO underpricing, the long-term post-IPO underperformance and the hot issue market - are extensively documented in the financial literature. In this paper we concentrate on the IPO initial underpricing issue and offer a new partly explanation for the phenomenon: election gimmick hypothesis.

The paper is organised as follows. First, we review the existing literature and develop our hypothesis. Second, we present our data sources and research methods employed. We focus our research on the Polish market, which is the biggest and most liquid post-soviet transition market among the CEE countries. We perform out computations based on filtered sample of 250 companies, which offered their shares on IPOs in the 01/01/2005-10/31/2013 timeframe. Third, we present our empirical research results. The paper ends with conclusions and suggestions for further research.

The investigations in this paper extends the academic knowledge in four ways. First, we offer the new explanation of the underpricing effect. Second, we test empirically its implications, which are important for investors and reg- 
ulators. Third, we deliver fresh out-of-sample evidence on the IPO underpricing phenomenon on the Polish market. Finally, from the methodological point of view, we propose an innovative Monte-Carlo-based technique to draw some statistical interferences.

\section{LiteratuRE REVIEW AND HyPOTHESIS DEVELOPMENT}

IPO underpricing is a long observed phenomenon in the financial literature. Positive abnormal excess returns in the first day of shares' listing has been documented for over three decades. The initial returns across the world ranges from $5 \%$ to over $50 \%$ some interesting reviews of research can be found in papers of Loughram, Ritter and Rydqvist (1994), Ibbotson and Ritter (1995), Jenkinson and Ljungqvist (2001).

The existing literature offers a number of explanations which partly or entirely explain the issue of initial IPO underpricing. Probably the most popular is the "winner's curse" hypothesis (Rock 1986), which emphasizes the tendency for the winning bid in an auction to exceed the intrinsic value of the company, that is difficult to determine. Some other popular explanations include singaling (Allen \& Faulhaber 1989; Grinblatt \& Hwang 1989; Welch 1989), selfinterest of investment bankers (Baron \& Holmstrom 1980; Baron 1982), bookbuilding (Benveniste \& Spindt 1989), market incompleteness (Mauer \& Senbet 1992), information cascades (Welch 1992), lawsuit avoidance (Tinic 1988; Hughes \& Thakor 1992) or cost compensation for individual investors (Kaminski \& Zaremba 2011). Some of the explanations focus particularly on local country factors, like for example regulatory constraints in the Chinese market (Tian 2011; Yuan 2009). Reviews of theories are offered for example by Ritter (2003) or Ritter and Welch (2002).

The hypothesis listed above provide a wide range of explanations of the initial IPO underpricing. However, they are not able to fully account for the cross-sectional variation in the abnormal returns connected to their original ownership structure. In some emerging markets, like for instance in Poland, there seem to be some differences in characteristics of privately-owned and state-owned IPOs. Clearly, the ownership structure may not entirely explain "the money left on the table" phenomenon, but it may seriously contribute to it. Therefore, we would like to propose a partial explanation of the IPO underpricing: an election gimmick hypothesis, which basically assumes, that some of the money left on the table may be a form of political bribery aimed at voters. 
There many ways of privatization of state-owned companies, but the stock exchange IPO is one of the most popular among the big ones. The benefits of this choice lay mainly in the transparency of the process. Nonetheless, one of the main drawbacks from the treasury point of view is the issue of the money left on the table, which may lead to an assumption that the treasury does not really maximize its profits. The IPOs of state owned companies offered to both institutional and individual investors. In some countries there are even a specific stare-sponsored programs and social campaigns aimed at popularizing the stock ownership. The Polish State Treasury sponsored "Citizen Share Ownership" programme is just one of the examples.

The key problem with such kind of programmes is an inherent conflict of interest. On the one hand, the treasury should maximise its income by selling the shares of state-owned enterprises at the maximum attainable price. On the other hand, the government and the ruling party may be motivated to intentionally lower the prices of offered shares in order to endear the voters by giving them an easy profit.

The hypothesis, that the prices of state-owned enterprises may be intentionally decreased to please the voters, have a few testable implications. First, the politicians may leave more money on the table than the private-company owners. In other words, we can assume that the state owned companies are more underpriced at IPOs that standard companies. Second, the politicians would be more enticed to sell the underpriced shares when the elections are coming. Briefly speaking, there would be more money left on the table before the elections than in other periods. Taking that into account, we test to prepositions in this paper.

I. The shares of state-owned companies are more underpriced at IPOs than the rest of the shares of privately-owned companies.

II. There is more money left on the table in the periods before elections than in other periods.

The both inclinations have high importance, particularly from the regulatory bodies' and investors' point of view.

Additionally, the problem seems to be economically and politically significant. According to KDPW (central infrastructure institution responsible for the management and supervision of the depository, clearing and settlement system) in at the end of 2013 Polish investors had about 1,5 million open brokerage accounts. In other words, along with their families, investors may constitute even 10 of the voters. Additionally, Treasury sometimes offers various mecha- 
nisms, which particularly favour broad participation in state-owned IPO, like for example subscription limits or emission price differentiation. Summing up, it appears rational to assume, that influencing their political preferences by IPO underpricing may significantly impact the results of some elections.

\section{Data Source AND Research Methods}

The research in this paper is based on the stock IPOs at the Polish market. We decided to focus on the CEE countries as those are post-soviet economies, which underwent a transition from state-dominated to private-capital dominated regime, and finally in many cases entered the European Union. Therefore, they seem to be an ideal laboratory to test the indicated hypotheses. The exact choice is Poland, as it is the post-soviet member of the EU with the biggest stock market both in terms of capitalization and liquidity. We concentrate on the period $01 / 01 / 2005-10 / 31 / 2013$, as it is the period when both the Polish economy and stock market were relatively mature (stable and low inflation, considerable liquidity in the market, technical and institutional advancement). What is more, the precise data on the IPOs, like issue sizes etc., are available for these years. We exclude from the sample two particular types of IPOs, which are IPOs dedicated only to previous shareholders and the share transfers form other markets. It is also important to note, that We do not take into account the NewConnect, which the Polish alternative platform dedicated to start-up companies with limited regulatory and reporting requirements. Finally, the sample includes 250 IPOs of which 18 are privatizations of state-owned companies. The data come from Bloomberg and databases of the Warsaw Stock Exchange.

In order to test the hypothesis I, we initially compute the arithmetic initial returns for each share in the sample according to standard rate of return computation equation.

$$
r_{j}^{A}=\frac{P_{j}^{C}-P_{j}^{O}}{P_{j}^{O}},
$$

where is $j$ - share's initial return, is the first day closing price and is the IPO offer price. Next, we calculated the average initial underpricing among privatized and previously privately owned companies. However, it is necessary to point out that such comparison may be not entirely meaningful in terms of sam- 
ples' comparability. The offers' sizes of privatized companies are usually significantly larger and it is a widely accepted fact that both the size of the company (Megginson \& Weiss 1991; Kiymaz 2000; Bhabra \& Pettway 2003; Ibbotson et al. 1994; Carter et al. 1998) and the issue itself (Chalk \& Peavy 1987; Clarkson \& Merkley 1994) impacts the level of underpricing. Therefore, we take a few additional approaches. First, we compare offer-size-weighted averages of privately-owned and state-owned companies. Second, we create a comparable subsample of size matched companies. For the subsample of the 19 state-owned companies we choose 19 offer-size matched privately-owned companies. The matching procedure is that we take companies with the closest offer size. In case of repetitions in the matched subsample, we choose the second closest IPO etc. Having done that, we compare average (standard and offer-size-weighted) initial returns in the both subsamples. Finally, we perform a few regressions and we use dummy variables as proxies for the pre-IPO ownership structure. We regress IPOs' initial logreturns against ownership dummies, natural logarithms of the offer size and past year's stock market logreturns. We introduce the last control variable into the model as numerous studies suggest that the market conditions preceding the IPO may influence the initial abnormal return (Derrien \& Womack 2003; Loughran \& Ritter 2002; Lowry \& Schwert 2002; Derrien 2005). We employ the WIG Index as the market proxy. The WIG Index is the broadest capitalization weighted index of the Polish stock market. It is calculated in the total return convention We perform the regressions separately for the full and matched samples.

In order to test the hypothesis II, we concentrated only on the state-owned companies. We first compute the amount of money left on the table in case of each IPO. We define the money left on the table according to a standard formula:

$$
m_{j}=S_{j} \times r_{J}^{A}
$$

where is the amount of money left in on the table during the $j$ IPO, is the offer size and is the initial abnormal return computed as it is described in the equation (1). Next, we divide all the IPOs into two groups. The first group includes the IPOs which took place in the 12 months preceding the election and the other group all the remaining offerings. We take into account both parliamentary and local elections. The list of all elections investigated in the study is presented in the table 1. 
Table 1. Elections in Poland

\begin{tabular}{|l|l|}
\hline \hline \multicolumn{1}{|c|}{ Type of elections } & Date \\
\hline \hline Parliamentary elections 2005 & $2005-09-25$ \\
\hline Local elections 2006 & $2006-11-12$ \\
\hline Parliamentary elections 2007 & $2007-10-21$ \\
\hline Local elections 2010 & $2010-11-21$ \\
\hline Parliamentary elections 2011 & $2011-08-04$ \\
\hline \hline
\end{tabular}

S o u r c e : own calculations.

The table 1. presents the elections in Poland in years 2005-2013. The Polish political system assumes elections every four years, however if the government resigns, the elections may happen more often. The local elections take place simultaneously in the whole country.

After that, we calculate the average amounts of money left on the table in the pre-election years and in the standard years. Finally, we use Monte Carlo simulations to test whether there is more money left on the table in the election years. The detailed Monte Carlo procedure is as follows. Our research period encompasses 3227 days, so we build a time series of 3227 days with indication whether each days was in the election year and optionally how much money was left on the table, if any IPO of a previously state-owned company happened that day. Next, we perform 10000 draws with replacements from the 3227 day sample. As the result, we obtain 10000 samples of 3227 days with varying number of election and IPO days. Based on that, we compute the average annual amount of money left on the table during election and non-election years. Eventually, we use standard parametrical methods to test the statistical significance of differences in the both amounts.

\section{RESULTS AND INTERPRETATION}

The table 2 presents the average returns on the IPOs of state-owned companies and non-state-owned companies. Provided that we take the offer size into consideration, the state-owned companies performed better than the remaining companies. The differences in initial rates of return vary from 2.60 p.p. to 4.62 p.p. dependent on the weighting method and sample structure. However, it is important to note, that the differences are actually statistically insignificant 
at any reasonable level. The reason for that may be a relatively small sample of highly variable returns.

Table 2. Initial returns at state-owned and privately-owned IPOs

\begin{tabular}{|c|c|c|c|c|c|c|}
\hline & \multicolumn{3}{|c|}{ Equal weighting } & \multicolumn{3}{|c|}{ Offer-size weighting } \\
\hline & Average & $\begin{array}{l}\text { Standard } \\
\text { deviation }\end{array}$ & Sample size & Average & $\begin{array}{l}\text { Standard } \\
\text { deviation }\end{array}$ & Sample size \\
\hline \multicolumn{7}{|c|}{ Full samples } \\
\hline State-owned companies & $\begin{array}{c}7.90 \% * * * \\
(2.89)\end{array}$ & $11.91 \%$ & 19 & $\begin{array}{c}8.89 \% * * * \\
\text { (4.29) }\end{array}$ & $9.03 \%$ & 19 \\
\hline Privately-owned companies & $\begin{array}{c}8.08 \% * * * \\
(5.79)\end{array}$ & $21.20 \%$ & 231 & $\begin{array}{c}6.29 \% * * * \\
(7.00)\end{array}$ & $13.68 \%$ & 231 \\
\hline Diference & $\begin{array}{l}-0.18 \% \\
(-0.06)\end{array}$ & & & $\begin{array}{l}2.60 \% \\
(1.15)\end{array}$ & & \\
\hline \multicolumn{7}{|c|}{ Matched samples } \\
\hline State-owned companies & $\begin{array}{c}7.90 \% * * * \\
(2.89)\end{array}$ & $11.91 \%$ & 19 & $\begin{array}{c}8.89 \% * * * \\
(4,29)\end{array}$ & $8.84 \%$ & 19 \\
\hline Privately-owned companies & $\begin{array}{l}3.28 \% \\
(1.29)\end{array}$ & $11.11 \%$ & 19 & $\begin{array}{c}4.92 \% * * * \\
(3.31)\end{array}$ & $6.49 \%$ & 19 \\
\hline Diference & $\begin{array}{l}4.62 \% \\
(1.24)\end{array}$ & & & $\begin{array}{l}3.97 \% \\
(1.58)\end{array}$ & & \\
\hline
\end{tabular}

S o u r c e : own calculations. Number in bracket is t-stat.

The table 2. depicts the average returns the average initial returns during the first day of trading at state-owned and privately-owned IPOs. The data on prices comes from Bloomberg and the detailed data on IPOs' dates and sizes come from databases of the Warsaw Stock Exchange. The computations are based on a filtered sample of IPOs from the Polish market in the period $01 / 01 / 2005-10 / 31 / 2013$. The symbols ${ }^{*}, * *$ and ${ }^{* * *}$ denote numbers statistically different than zero at $10 \%, 5 \%$ and $1 \%$ level.

The results above are generally consistent with the effects of the regression analysis (table 3). When we regress the initial log returns in the matched-samples, the ownership dummy usually indicates bigger returns in case of privatized companies. Nonetheless, again, the statistical significance is rather weak. Moreover, it is quite interesting, that when we perform the regressions based on full sample, the ownership dummy sometimes becomes negative. However, 
we strongly feel that it may be due to model's misspecification. It is very difficult what exactly is the functional form of the relation between the offer size and the initial return. As the distribution of offer sizes is highly skewed contrary to the distribution of returns, the linear approximation is probably not ideal (in the preliminary computations we obtained more reasonable results with other functional forms, however the true relation was difficult to settle; as a reason of that, we decided to use the simplest linear form and perform parallel the regression based on offer-size-matched samples). We strongly feel that the regression based on matched samples yields will give informative results.

Table 3. Impact of explanatory variables on initial IPO returns

Panel A: full sample.

\begin{tabular}{|c|c|c|c|c|}
\hline \hline & $\mathbf{( 1 )}$ & $\mathbf{( 2 )}$ & $\mathbf{( 3 )}$ & \multicolumn{1}{c|}{ (4) } \\
\hline \hline \multirow{2}{*}{ int } & $8.08 \% * * *$ & $3.12 \% * *$ & $-6.63 \%$ & $13.90 \%$ \\
& $(5.94)$ & $(1.97)$ & $(-0.4)$ & $(0.88)$ \\
& -0.002 & 0.020 & -0.026 & 0.039 \\
& $(-0.0)$ & $(0.04)$ & $(-0.4)$ & $(0.71)$ \\
mrk & & $0.274^{* * *}$ & & $0.285^{* * *}$ \\
& & $(5.45)$ & & $(5.40)$ \\
size & & & 0.008 & -0.006 \\
& & & $(0.91)$ & $(-0.6)$ \\
\hline Dop. R^2 & $0.00 \%$ & $10.02 \%$ & $0.34 \%$ & $9.83 \%$ \\
\hline N & 250 & 250 & 250 & 250 \\
\hline F-stat & 0.00 & 14.86 & 0.42 & 10.05 \\
\hline \hline
\end{tabular}

Panel B: size-matched sample.

\begin{tabular}{|c|c|c|c|c|}
\hline \hline & $\mathbf{( 1 )}$ & (2) & (3) & \multicolumn{1}{c|}{ (4) } \\
\hline \hline int & $3.28 \%$ & $-0.29 \%$ & $-20.76 \%$ & $-17.37 \%$ \\
& $(1.24)$ & $(-0.1)$ & $(-0.6)$ & $(-0.5)$ \\
\multirow{2}{*}{ own } & 0.046 & $0.065^{*}$ & 0.042 & $0.062^{*}$ \\
& $(1.23)$ & $(1.83)$ & $(1.11)$ & $(1.70)$ \\
& & $0.163^{* *}$ & & $0.160^{* *}$ \\
\hline
\end{tabular}




\begin{tabular}{|c|c|c|c|c|}
\hline \hline & (1) & (2) & (3) & (4) \\
\hline \hline \multirow{2}{*}{ size } & & $(2.52)$ & & (2.43) \\
& & & 0.012 & 0.008 \\
& & & $(0.76)$ & $(0.57)$ \\
\hline Adj. R & $1.40 \%$ & $14.25 \%$ & $0.25 \%$ & $12.60 \%$ \\
\hline N & 38 & 38 & 38 & 38 \\
\hline F-stat & 1.53 & 4.08 & 1.05 & 2.78 \\
\hline \hline
\end{tabular}

S o u r c e : own calculations. Number in bracket is t-stat.

The regression model estimated for initial IPO logreturns is based on a filtered sample of IPOs from the Polish market and encompasses the 01/01/200510/31/2013 timeframe. The explanatory variables are named as follows: int denotes an intercept, own is a dummy variable, which is equal 1 for IPOs of stateowned companies and 0 for privately-owned companies, mrk is the WIG Index logreturn in 12 months preceding the IPO and size a natural logarithm of an offer size. The first number in each cell is the OLS estimation of the coefficient for the corresponded variable. Numbers in brackets are the t-statistics. " $\mathrm{N}$ " is the number of observations. The symbols $*{ }^{* *}$, and ${ }^{* * *}$ denote the statistical significance at the $10 \%, 5 \%$ and $1 \%$ levels. The data come from the Warsaw Stock Exchange and Bloomberg. The Panel A depicts the analysis based on the full sample and the Panel B presents the regression based on a size-matched sample.

The computation of the average annual money left on the table in election and non-election years confirms our initial intuitions (table 4). The amounts in 12 months preceding the elections are over twice bigger than in the remaining months. However, similarly as in the previous case, the Monte Carlo simulations indicates that the differences are not statistically significant. Again, we feel we should blame relatively small sample for that. 
Table 4. Money left on the table in election and non-election years

\begin{tabular}{|c|c|c|c|c|c|c|}
\hline & Years & $\begin{array}{l}\text { Years' frac- } \\
\text { tion }\end{array}$ & $\begin{array}{l}\text { Total offer } \\
\text { size }\end{array}$ & $\begin{array}{l}\text { Total money } \\
\text { left on the } \\
\text { table }\end{array}$ & Offers p.a. & $\begin{array}{c}\text { Money left } \\
\text { on the table } \\
\text { p.a. }\end{array}$ \\
\hline & [years] & [\%] & [mio. PLN] & [mio. PLN] & [mio. PLN] & [mio. PLN] \\
\hline Election years & 4.37 & $49.6 \%$ & 23776 & 2258.60 & 5438 & 517 \\
\hline Non-election years & 4.44 & $50.4 \%$ & 11042 & 1126.94 & 2485 & 254 \\
\hline Difference & & & & & 2953 & 263 \\
\hline t-stat & & & & & & (0.917) \\
\hline
\end{tabular}

S o u r c e : own calculations.

The table 4. Presents the amounts of the money left on the table at IPOs of state owned companies in Poland in the 01/01/2005-10/31/2013 timeframe. The information in squared brackets denote units. The average USD/PLN exchange rate in the research period was about 3.00 PLN per USD. A number in round bracket is the t-statistics. The symbols ${ }^{*},{ }^{* *}$, and ${ }^{* * *}$ denote the statistical significance at the $10 \%, 5 \%$ and $1 \%$ levels. The data come from the Warsaw Stock Exchange and Bloomberg.

Figure 1. Money left on the table - the simulation analysis

Panel A: amounts of money left on the table in election and non-election years.

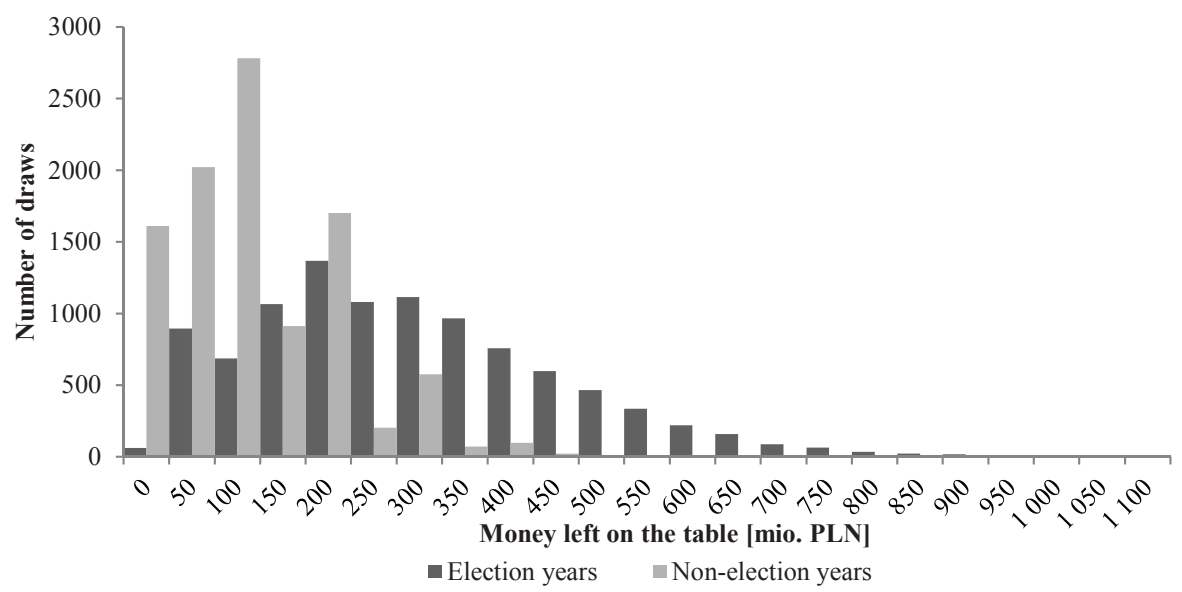


Panel B: differences in amounts of money left on the table in election and non-election years.

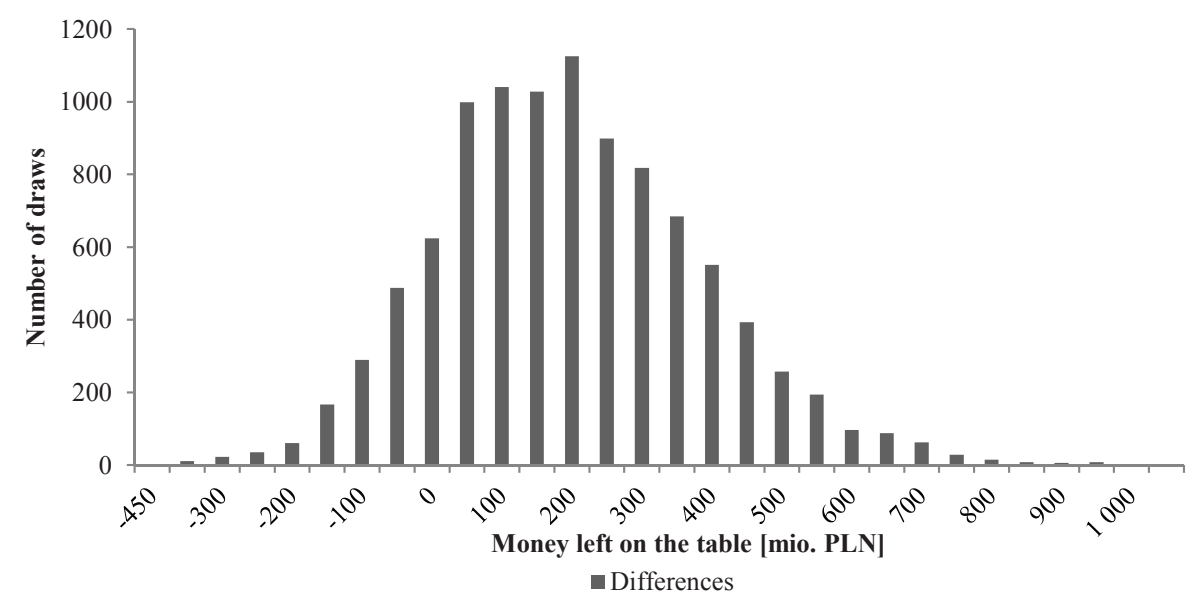

S o u r c e : authors' elaboration.

The Monte Carlo analysis of the differences in the amounts of money left on the table in election and non-election years is performed based on 10000 draws. The detailed procedure of the simulations and statistical interfering is described in the main paper. The average USD/PLN exchange rate in the research period was about 3.00 PLN per USD. The Panel A shows the separate draws for the election and non-years and the Panel B presents differences between the two types of years computed for every draw.

\section{CONCLUSIONS AND AREAS FOR FURTHER RESEARCH}

In this paper we offer a new hypothesis explaining part of the "money left on the table" puzzle. The political gimmick hypothesis states, that the ruling party and the treasury may be motivated to intentionally leave some money on the table during the IPOs of state-owned enterprises to please the voters. We investigate empirically two testable implications of the hypothesis: that the privatization IPOs yield higher initial returns and that there is more money left on the table when the elections are coming. Generally, out computations confirm both intuitions. However, we encounter obstacles in our computations, which are quite characteristic for emerging markets' studies and which are difficult to overcome. The statistical significance of our results is rather weak, which 
could be a result of rather small sample available, although we focused on the biggest and most liquid CEE country.

The paper brings three important findings and implications about capital market. Investors should pay attention to the nature of ownership of the company before the IPO (state/private owner), because it may be important as a determinant of instantaneous post-IPO rates of return. In addition, conclusions of the paper constitute a contribution for future studies on the effectiveness of state-owned assets within the conflict of interest problem. There are also important conclusions for the voters who should more carefully analyse the purpose and conditions of IPOs of state-owned companies .

The research initiated in this paper should be continued and the developed in the future. The further investigations should primarily concentrate on expanding the sample size, both in spatial and time terms. It seems that the research could be repeated for some other markets and performed again in the future. Second, it would be interesting to include more explanatory variables in the regression and better specify the model. Third, the further analyses may try to precisely asses to what extend the election gimmick's impact contributes to the initial underpricing. Finally, it should be investigated whether the election cycles affect also other IPO anomalies, like the hot issue market or the longterm post-offering underperformance.

\section{UII REFERENCES}

Allen F. \& Faulhaber G.R. (1989). Signaling by Underpricing in the IPO Market. Journal of Financial Economics, 23, 303-323. http://dx.doi.org/10.1016/0304-405X(89) 90060-3.

Baron D.P. \& Holmstrom B. (1980). The Ivestment Banking Contract for New Issues Under Asymmetric Information: Delegation and the Incentive Problem. Journal of Finance, 35, 1115-1138.

Baron D.P. (1982). A Model of the Demand for Investment Banking Advising and Distribution Services for New Issues. Journal of Finance, 37, 955-976.

Benveniste L.M. \& Spindt P.A. (1989). How Investment Bankers Determine the Offer Price and Allocation of New Issues. Journal of Financial Economics, 24, 343-361. http://dx.doi.org/10.1016/0304-405X(89)90051-2.

Bhabra H.S. \& Pettway R.H. (2003). IPO prospectus information and subsequent performance. Financial Review, 38, 369-397. http://dx.doi.org/10.1111/1540-6288.00051.

Carter R., Dark F. \& Singh A. (1998). Underwriter reputation, initial returns, and the long-run performance of IPO stocks. The Journal of Finance, 53, 285-311. http://dx.doi. org/10.1111/0022-1082.104624. 
Chalk A.J. \& Peavy J.W. (1987). Initial Public Offerings: Daily Returns. Offering Types and the Price Effect. Financial Analysts Journal, 43, 65-69. http://dx.doi.org/10.2469/ faj.v43.n5.65.

Clarkson P. M. \& Merkley J. (1994). Ex Ante Uncertainty and the Underpricing of Initial Public Offerings: Further Canadian Evidence. Canadian Journal of Administrative Sciences, II, no. 1, 54-67. http://dx.doi.org/10.1111/j.1936-4490.1994.tb00054.x.

Derrien F. (2005). IPO Pricing in Hot Market Conditions: Who Leaves Money on the Table? Journal of Finance, 60 (1), 487-521. http://dx.doi.org/10.1111/j.1540-6261. 2005.00736.x.

Derrien F. \& Womack K.L. (2003). Auctions vs. Bookbuilding and the Control of Underpricing in Hot IPO Markets. Review of Financial Studies, 16, 31-61. http://dx.doi. org/10.1093/rfs/16.1.31.

Grinblatt M. \& Hwang C.Y. (1989). Signaling and the Pricing of New Issues. Journal of Finance, 44, 393-420. http://dx.doi.org/10.2307/2328596.

Hughes P.J \& Thakor A.V. (1992). Litigation Risk, Intermediation and the Underpriccing of Initial Public Offerings. Review of Financial Studies, 5, 709-742. http://dx.doi. org/10.1093/rfs/5.4.709.

Ibbotson R. G., Sindelar J. \& Ritter J. (1994). The market's problems with the pricing of initial public offerings. Journal of Applied Corporate Finance, 7, 66-74. http:// dx.doi.org/10.1111/j.1745-6622.1994.tb00395.x.

Ibbotson R.G. \& Ritter J.R. (1995), Initial Public Offerings, [in:] Finance, R. A. Jarrow, V. Maksimovic, W. T. Ziemba (eds.), Elsevier, Amsterdam, 993-1016.

Jenkinson T. \& Ljungqvist A. (2001), Going Public: The Theory and Evidence on how Companies Raise Equity Finance, Oxford University Press, Oxford.

Kaminski K. \& Zaremba A. (2011). IPOs - not so much Money on the Table: The Cost Compensation Hypothesis, Argumenta Oeconomica, available at SSRN: http://ssrn. com/abstract=2349904.

Kiymaz H. (2000). The initial and aftermarket performance of IPO's in an emerging market: evidence from Istanbul Stock Exchange. Journal of Multinational Financial Management, 10, 213-227.

Loughram T., Ritter J.R. \& Rydqvist K. (1994). Initial Public Offerings: International Insights. Pacific-Basin Finance Journal, 2, 165-199.

Loughran T., Ritter J.R. (2002). Why don't issuers get upset about leaving money on the table in IPOs?. Review of Financial Studies, 15, 413-443.

Lowry M., Schwert W. (2002). IPO market cycles: Bubbles or sequential learning?. Journal of Finance, 57, 1171-1200.

Mauer D.C. \& Senbet W.S. (1992). The Effect of the Secondary Market on the Pricing of Initial Public Offerings: Theory and Evidence. Journal of Financial and Quantitative Analysis, 24, 55-79.

Megginson W.L. \& Weiss K.A. (1991). Venture capitalist certification in initial public offerings. Journal of Finance, 46, 879-903.

Ritter J. (2003), Investment banking and securities issuance, [in:] Handbook of the Economics of Finance, G. Constantinides, M. Harris \& R. Stulz (eds.), Elsevier, Amsterdam. 
Ritter J., Welch I. (2002). A review of IPO activity, pricing, and allocations. The Journal of Finance, 57 (4), 1795-1828.

Rock K. (1986). Why New Issues are Underpriced. Journal of Financial Economics, 15, 187-2012.

Tian L.G. (2011). Regulatory underpricing: Determinants of Chinese extreme IPO returns. Journal of Empirical Finance, 18 (1), 78-90.

Tinic S.M. (1988). Anatomy of Initial Public Offerings of Common Stock. Journal of Finance, $43,789-822$.

Welch I. (1989). Seasoned Offerings, Imitation Costs and the Underpricing of Unitial Public Offerings. Journal of Finance, 44, 421-449.

Welch I. (1992). Sequential Sales, Learning and Cascades. Journal of Finance, 47, 695-732 .

Yuan J. (2009). Alternative explanations of under-pricing of Chinese initial public offerings, PhD thesis, University of Nottingham. 